\title{
Conditioned food aversion to Ipomoea carnea var. fistulosa induced by Baccharis coridifolia in goats ${ }^{1}$
}

\author{
Maria de Lourdes Adrien², Gabriela Riet-Correa ${ }^{3}$, Carlos Alberto de Oliveira ${ }^{3}$, James A. \\ Pfister ${ }^{4}$, Daniel Cook ${ }^{4}$, Elda G. Souza ${ }^{3}$, Franklin Riet-Correa ${ }^{5}$ and Ana Lucia Schild ${ }^{6 *}$
}

\begin{abstract}
Adrien M.L., Riet-Correa G., Oliveira C.A., Pfister J.A., Cook D., Souza E.G., Riet-Correa F. \& Schild A.L. 2013. Conditioned food aversion to Ipomoea carnea var. fistulosa induced by Baccharis coridifolia in goats. Pesquisa Veterinária Brasileira 33(8):999-1003. Laboratório Regional de Diagnóstico, Faculdade de Veterinária, Universidade Federal de Pelotas, Campus Universitário s/n, Pelotas, RS 96010-900, Brazil. E-mail: alschild@terra.com.br

Baccharis coridifolia is a plant that induces strong conditioned food aversion in ruminants. This research aimed to induce a conditioned food aversion to Ipomoea carnea var. fistulosa in goats, using $B$. coridifolia as an aversive agent, and to compare the aversion induced by this plant with the aversion induced by lithium chloride ( $\mathrm{LiCl}$ ). Thirteen goats were allotted into two groups: Group 1 with six goats was averted with $175 \mathrm{mg} / \mathrm{kg}$ of body weight of $\mathrm{LiCl}$ and Group 2 with seven goats was averted with $0,25 \mathrm{~g} / \mathrm{kg}$ of bw of dried $B$. coridifolia. All goats were averted on day 1 after the ingestion of I. carnea. The aversion procedure with $\mathrm{LiCl}$ or B. coridifolia in goats from Groups 1 and 2, respectively, was repeated in those goats that again consumed the plant during tests on days 2,3 , and 7 . The goats of both groups were challenged in pens on 23 and 38 days after the last day of aversion and challenged in the pasture on days $11,15,18,20,22,25,27$ and 29 after the last day of aversion. After this period goats were challenged every 15 days on pasture until the $330^{\circ}$ day after the last day of aversion (7th day). Two goats from Group 1 ingested I. carnea on the first day of the pasture challenge, 4 days after the last day of aversive conditioning in the pen. In addition, another goat in Group 1 started to consume the plant on day 18, and other two goats ate it on day 20. One goat in Group 1 that had never eaten I. carnea died on day 155. One goat from Group 2 started to ingest I. carnea on the first day of the pasture challenge, and a second goat started to consume this plant on day 182. At the end of the experiment, on day 330, the other five goats averted with B. coridifolia remained averted. These results suggest that $B$. coridifolia or an active compound from the plant could be used to induce aversion to toxic plants. Using B. coridifolia would be cheaper and, particularly in flocks with large number of animals, possibly easier than using $\mathrm{LiCl}$, which requires the use of oral gavage and qualified personnel for its implementation.
\end{abstract}

INDEX TERMS: Poisonous plants, Ipomoea carnea var. fistulosa, Convolvulaceae, food aversion, swainsonine, plant poisoning.

RESUMO.- [Aversão alimentar condicionada de Ipomoea carnea var. fistulosa induzida por Baccharis coridifolia em caprinos.] Baccharis coridifolia é uma planta tóxica que possui forte poder aversivo em ruminantes. Os objeti-

\footnotetext{
${ }^{1}$ Received on June 11, 2013.

Accepted for publication on July 26, 2013.

${ }^{2}$ Pós-Graduanda em Veterinária, Faculdade de Veterinária, Universidade Federal de Pelotas (UFPel), Campus Universitário s/n, Caixa postal 354, Pelotas, RS 96010-900, Brazil. Bolsista CAPES/UDELAR.

${ }^{3}$ Central de Diagnóstico Veterinário, Escola de Veterinária, Universidade Federal do Pará UFPA), Rua Maximino Porpino da Silva 1000, Pirapora, Castanhal, PA 68743-080, Brazil.
}

vos deste trabalho foram induzir aversão condicionada a Ipomoea carnea var. fistulosa em caprinos utilizando B. coridifolia como agente aversivo e comparar a eficiência desta aversão com a aversão induzida por cloreto de lítio (LiCl).

\footnotetext{
${ }^{4}$ USDA-ARS, Poisonous Plant Research Laboratory, 1150 E. 1400 N., Logan, UT 84341, USA.

${ }^{5}$ Hospital Veterinário, Centro de Saúde e Tecnologia Rural (CSTR), Universidade Federal de Campina Grande (UFCG), Campus de Patos, Avenida Universitária s/n, Santa Cecília, Patos, PB 58708-110, Brazil.

${ }^{6}$ Laboratório Regional de Diagnóstico, Faculdade de Veterinária, UFPel, Campus Universitário s/n, Caixa postal 354, Pelotas, RS. *Corresponding autor: alschild@terra.com.br
} 
Treze cabras foram divididas em dois grupos: o Grupo 1 com seis cabras foi avertido com $175 \mathrm{mg} / \mathrm{kg}$ de peso corporal (pc) de LiCl e o Grupo 2, com sete cabras, foi avertido com $0,25 \mathrm{~g} / \mathrm{kg}$ de pc de $B$. coridifolia seco. Todas as cabras foram avertidas no dia 1 logo após a ingestão de I.carnea. A aversão foi repetida nos dias 2, 3 e 7 nos caprinos que ingeriram qualquer quantidade de I. carnea, utilizando-se o mesmo procedimento do dia 1. Os caprinos de ambos os grupos foram desafiados nas baias nos dias 23 e 38 após o último dia da aversão e desafiados na pastagem nos dias $11,15,18,20,22$, 25, 27 e 29 após o último dia da aversão. Posteriormente os caprinos foram desafiados a cada 15 dias na pastagem até o $330^{\circ}$ dia após o último dia da aversão (7º dia). Duas cabras do Grupo 1 ingeriram I. carnea no primeiro dia do desafio na pastagem, quatro dias após o ultimo dia da aversão nas baias. Além disso, outra cabra do mesmo grupo reiniciou a ingestão da planta no $18^{\circ}$ dia e outras duas no $20^{\circ}$ dia. Uma cabra do Grupo 1 que nunca havia ingerido a planta após a aversão morreu no 55 dia. Uma cabra do Grupo 2 começou a ingerir I. carnea no primeiro dia de desafio na pastagem e uma segunda reiniciou o consumo da planta no $182^{\circ}$ dia. No final do experimento no $330^{\circ}$ as cinco cabras avertidas com $B$. coridifolia permaneciam sem ingerir a planta. Estes resultados sugerem que $B$. coridifolia ou algum princípio ativo dessa planta pode ser utilizado para induzir aversão condicionada a plantas tóxicas. A utilização de B. coridifolia como agente aversivo é aparentemente mais barato e mais fácil de ser utilizado do que o $\mathrm{LiCl}$, o qual requer o uso de sonda oro-gástrica e pessoal qualificado para sua implementação.

TERMOS DE INDEXAÇÃO: Plantas tóxicas, Ipomoea carnea var. fistulosa, Convolvulaceae, aversão alimentar, swainsonina, intoxicação por plantas.

\section{INTRODUCTION}

Ipomoea carnea var. fistulosa (Convolvulaceae) is a plant that contains swainsonine and causes poisoning in goats (Armién et al. 2007, De Balogh et al. 1999, Oliveira et al. 2009, Silva et al. 2006), cattle (Antoniassi et al. 2007), and probably sheep (Tokarnia et al. 1960, Armién et al. 2011). The intoxication has been experimentally reproduced in goats and sheep (Tokarnia et al. 1960, Armién et al. 2011). The poisoning is characterized by clinical neurological signs without macroscopic lesions. The histological lesions are characterized by vacuolization of some epithelial and lymphatic cells, and neurons (De Balogh et al. 1999, Antoniassi et al. 2007, Armién et al. 2007, 2011, Oliveira et al. 2009). Due to the often severe and prolonged dry season in northeastern of Brazil, I. carnea has greater importance as a toxic plant in this region than other parts of Brazil, particularly causing persistent livestock losses in the São Francisco River Valley, and south of the state of Piauí. I. carnea is one of the few plants that remain green during the dry season (Tokarnia et al. 2012).

Conditioned food aversion is used to prevent the ingestion of toxic plants by ruminants. Lithium chloride ( $\mathrm{LiCl}$ ) is an aversive agent that has been used to induce aversion to Delphinium barbeyi in cattle (Olsen et al. 1989), Cercocarpus montanus and Amelanchier alnifolia in sheep (Burritt
\& Provenza 1990), and Amorimia rigida in goats (Barbosa et al. 2008) and sheep (Pacífico da Silva \& Soto-Blanco 2010).

The technique was also effective in conditioning goats to avoid consuming $I$. carnea during the rainy season, but not during the dry season, with low forage availability in the field (Pimentel et al. 2012). These results suggest that conditioned food aversion can be used in goats to control intoxication by some Brazilian swainsonine-containing plants. However, the cost of purchasing LiCl coupled with the need to give $\mathrm{LiCl}$ through a stomach tube are limiting factors for the use of this substance as an aversive agent, especially on farms with many animals. An aversive agent that is inexpensive and more easily administered to livestock would be a welcome addition to commercial farms with high numbers of animals.

Baccharis coridifolia (Asteraceae) is an important toxic plant for ruminants (Rissi et al. 2005, Rozza et al. 2006) and horses (Alda et al. 2009) in southern Brazil and in other South American countries (Barros 1998). This plant induces strong aversion when consumed in small amounts by animals raised in the areas where it grows (Barros 1998). Also when it was administered at non-toxic doses, the plant induced aversion in naïve animals about to be introduced into the infested areas (Almeida et al. 2013). In addition, this plant was used successfully for inducing aversion to corn in sheep (Almeida et al. 2009). The toxic compounds of the plant are macrocyclic trichothecenes (roridins $A$ and E, miotoxin A, B, C and D, miophytocen A, B and di-O-acetyl-verrucarol) produced by soil fungi such as Myrothecium verrucaria (Habermehl et al. 1985), but it is not known if these substances are responsible for the aversion.

The objective of this study was to determine if $B$. coridifolia (mio-mio) induced aversion to the consumption of $I$. carnea var. fistulosa in goats and to compare the efficacy of this aversion to the aversion induced by $\mathrm{LiCl}$.

\section{MATERIALS AND METHODS}

Thirteen naïve goats, two castrated males and 11 females 2-years of age (seven pregnant), were acquired from farms where they were grazing Brachiaria pastures. For 15 days after arrival, the animals were grazed in a Panicum maximum pasture that had no Ipomoea carnea, and at night they were penned and fed with increasing amounts of a commercial goat concentrate. After adaptation the goats were divided into groups of six goats (Group 1) or seven goats (Group 2). Group 1, for aversion with $\mathrm{LiCl}$, weighed $22.7 \pm 8.2 \mathrm{~kg}$, and Group 2, for aversion with Baccharis coridifolia, weighed $24.1 \pm 7.2 \mathrm{~kg}$. During the experimental period both groups of goats were grazed together during the day in a pasture of P. maximum var Tanzania, and at the end of the afternoon, the groups were penned in separate pens and fed with $200 \mathrm{~g}$ per goat of a commercial goat concentrate and offered water ad libitum.

Before the aversion, goats were exposed to freshly harvested $I$. carnea by offering branches containing stalks, leaves, flowers and fruits of this plant, which were suspended from the pen wall for $1 \mathrm{~h}$ daily for 3 consecutive days. The goats were considered to be no longer naïve when they ate at least 10 bites during any 10 -min period. It was estimated that the amount of plant consumed in 10 bites was sufficient to ensure that goats would associate the plant ingested with the negative effect of the aversive substance. 
To induce aversion to I. carnea, each experimental group was allowed to feed on green stalks of the plant suspended from the pen wall for $10 \mathrm{~min}$ (Day 1). At the end of the 10-min period, each goat from Group 1 that ate the I. carnea received, by oral gavage, $175 \mathrm{mg} / \mathrm{kg}$ of body weight of $\mathrm{LiCl}$ diluted with $1 \mathrm{~L}$ of water, whereas the goats from Group 2 that ate I. carnea were forced to ingest $0.25 \mathrm{~g} / \mathrm{kg}$ of body weight of dry B. coridifolia ( $25 \%$ of a toxic dose) by putting small amounts of this plant in their mouths. After the aversion treatment, the goats from both groups remained confined in two different pens with no access to food for $4 \mathrm{~h}$. After this period each group was fed with $200 \mathrm{~g}$ per goat of a concentrate commercial goat ration and remained in the pens until the next day. These procedures were repeated on Day 2, 3, and 7 for the goats that had eaten some amount of I. carnea. When I. carnea was offered to the goats, they were observed for 10 minutes to identify those that ingested the plant (Table1). On days 4-6 and after Day 7 , the goats were grazed during the day in a pasture of P. maximum var. Tanzania and at the end of the afternoon, they were penned and fed with 200 g per goat of a commercial goat concentrate and given water ad libitum.

From day 11 (4 days after the last day of aversion) to day 29, pasture challenges were performed allowing the goats to graze for 3 days a week, for $3 \mathrm{~h}$ daily, in a paddock of $471 \mathrm{~m}^{2}$ that contained I. carnea (1.2 plants of I. carnea per $\mathrm{m}^{2}$ ). Groups 1 and 2 grazed separately on different days to eliminate any social facilitation. The goats were observed to identify those that started to ingest $I$. carnea by a single person who was located approximately $10 \mathrm{~m}$ from the animals; the animals were accustomed to the human presence and the observations did not interfer with their behavior. After the challenges the goats were placed in the pasture of Panicum maximum var. Tanzania. On Days 23 and 38 the goats were challenged in the pens, with green stalks of I. carnea suspended from the pen wall for 10 min taking note of those animals who ate any amount of the plant. From day 47 to day 330, the animals from both groups grazed together in the area infested by I. carnea at 15 -day intervals for a $3 \mathrm{~h}$ period each day (19 grazing sessions). The total availability of forage in the area was visually estimated as $1,000 \mathrm{~kg} /$ ha of dry matter.

The B. coridifolia for this experiment was collected during the fall (April) in the state of Rio Grande do Sul. Trichothecenes in the plant were determined using UHPLC (Ultra High Performance Liquid Chromatography) with high resolution Time of Flight mass spectrometry and tandem mass spectrometry previously described (Oliveira-Filho et al. 2012). This analysis showed that the $B$. coridifolia used in this study contained several macrocyclic trichothecenes, but no concentrations were obtained. The toxicity of $B$. coridifolia was evaluated in goats prior to the experiment. For this evaluation, two goats received by gavage 1 and $0.5 \mathrm{~g} / \mathrm{kg}$ of body weight of $B$. coridifolia, respectively. Both animals had anorexia and profuse salivation, but all clinical signs resolved within $48 \mathrm{~h}$. With that background, the dose selected for this study was $0.25 \mathrm{~g} / \mathrm{kg}$ body weight, to ensure that no animals would be fatally poisoned.

Swainsonine concentration, determined by liquid chromatography-mass spectrometry (Gardner et al. 2001) of the aerial parts of I. carnea collected during the months of April and May of 2011 , was $0.05 \pm 0.01 \%$.

During the pasture challenge, seven goats gave birth (six goats in Group 2 and one goat in Group 1). The kids were confined in pens without access to the pasture.

To avoid social facilitation, the goats that were observed consuming $I$. carnea were removed from the group during the next challenges, but they remained grazing in the same $P$. maximum pasture. However, for statistical analysis, it was assumed that the goats remained in the group until the end of the trial. The number of goats that consumed I. carnea in Groups 1 and 2 was compared by Fisher's exact test (Frequency Procedure of SAS, SAS version 9.2). The significance level was $5 \%$.

\section{RESULTS}

The number of goats that consumed Ipomoea carnea and were averted with LiCl (Group 1) or B. coridifolia (Group 2 ) is presented in Table 1. Two goats averted with Baccharis coridifolia presented distinct clinical signs of temporary anorexia and salivation after ingesting the plant. No clinical signs were observed in the goats averted with $\mathrm{LiCl}$.

Table 1. Number of goats that consumed Ipomoea carnea in pen tests during and after the aversion procedure with $\mathrm{LiCl}$ (Group 1) or Baccharis coridifolia (Group 2)

\begin{tabular}{|c|c|c|c|c|c|c|}
\hline \multirow[t]{3}{*}{ Treatment } & \multicolumn{6}{|c|}{ Number of goats that consumed I. carnea in the pen tests } \\
\hline & \multicolumn{4}{|c|}{ Aversion days } & \multicolumn{2}{|c|}{ Challenge days } \\
\hline & Day 1 & Day 2 & Day 3 & Day 7 & Day 23 & Day 38 \\
\hline Grou & $6 a$ & $0 \mathrm{a}$ & $1 \mathrm{a}$ & $0 \mathrm{a}$ & $3 a$ & $0 \mathrm{a}$ \\
\hline Group $2(n=7)$ & $7 \mathrm{a}$ & $0 \mathrm{a}$ & $0 \mathrm{a}$ & $5 b$ & Ob & $0 \mathrm{a}$ \\
\hline
\end{tabular}

Different letters in the columns indicate significant differences $(\mathrm{P}<0.05)$ by Fisher's exact test between groups.

During the challenge in the pasture, there was a difference $(\mathrm{P}<0.05)$ in the lag time to start consumption of I. carnea between goats of the two groups (Table 2). Two goats from Group 1 ingested I. carnea on the first day of the pasture challenge, 4 days after the end of aversion conditioning. Another three goats started to consume the plant on day 18 (one goat) and on day 20 (two goats). One goat from Group 2 started to ingest I. carnea on the first day of the pasture challenge (Table 2).

Table 2. Number of goats that consumed Ipomoea carnea in pasture tests after being averted to the plant with $\mathrm{LiCl}$ (Group 1) or Baccharis coridifolia (Group 2)

Treatment Number of goats that consumed I. carnea in pasture tests Day 11 Day 15 Day 18 Day 20 Day 22 Day 25 Day 27 Day 29

Group $1(n=6) \quad 2 a \quad 2 a \quad 3 a \quad 5 a \quad 5 a \quad 5 a \quad 5 a \quad 5 a$

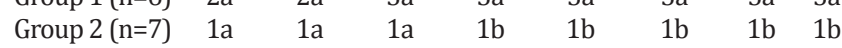

Different letters in the columns indicate significant differences $(\mathrm{P}<0.05)$ by Fisher's exact test between groups.

Three goats from Group 1 ingested I. carnea during the pen challenge on day 23 , but during the pen challenge on day 38 they did not consume the plant. None of the goats in Group 2 consumed I. carnea during these two challenges performed in the pens (Table 1 ).

During the pasture challenge from day 47 to day 330, one goat from Group 1 died of acute haemonchosis (a nematode infection) on day 155 , but it had not been observed ingesting I. carnea. One goat from Group 2 started to consume I. carnea on day 182. At the end of the experiment on day 330, five goats from Group 2 remained averted.

\section{DISCUSSION}

Baccharis coridifolia induced an aversion to the consumption of Ipomoea carnea in goats when they were exposed to the plant in the pasture. During the 330 days of the expe- 
riment, the conditioned aversion was complete in five out of seven goats averted with $B$. coridifolia. In contrast, the goats averted with $\mathrm{LiCl}$ experienced rapid extinction of the aversion (five out of six were not averted on day 20). Only one of these LiCl goats, which died of acute haemonchosis on day 155, was still averted at that time. Previous experiments had demonstrated that $B$. coridifolia is a strong aversive agent. This plant induced conditioned aversions to corn in sheep similar to that induced by $\mathrm{LiCl}$ (Almeida et al. 2009). The strong aversion induced by B. coridifolia is apparently due to its toxic effects on the digestive system (Almeida et al. 2009), which presumably provided negative post-ingestive feedback to the central nervous system (CNS). Current evidence suggests that CNS activation is essential for the acquisition of aversions (Bernstein 1999, Grigson et al. 1997, Reilly et al. 1993). It appears that in the absence of CNS activation, other biochemical and physiological lesions will not condition aversion (Yamamoto et al. 1998). Additionally, although nausea (i.e., digestive upset) is not essential for the acquisition of aversions, it may greatly potentiate the dislike of a specific food (Pelchat \& Rozin 1982).

Intoxication by $B$. coridifolia occurs only in naïve animals introduced into invaded pastures and is more common when recently transported animals are stressed, fatigued, hungry or thirsty. The animals born on farms that have this plant do not ingest it (Barros 1998), at least not after an initial negative experience. The ingestion of small amounts of $B$. coridifolia seems to be the mechanism of the naturally acquired aversion to this plant in animals born in areas where it grows (Almeida et al. 2009). A similar mechanism was suggested for goats that avoid ingesting Coleogyne ramosissima (Provenza et al. 1990). Ralphs and Provenza (1999) suggested that native animals develop natural aversions to many poisonous plants through individually learning via post-ingestive consequences.

Ipomoea carnea is not palatable for goats; outbreaks of intoxication occur when a shortage of forage compels some animals to ingest the plant and, by social facilitation, other goats are induced to ingest it (Oliveira et al. 2009). To induce an aversion in naïve animals, it is necessary for the animals to sample the target plant in order to pair the consequences of the aversive agent to its taste and smell. In previous experiments, aversion was induced after the goats ingested the plant readily for a period of 15 days (Riet-Correa 2012). In contrast, in this experiment the animals were averted after consumption of a few leaves of I. carnea (10 bites). It appears that this short period of ingestion of the plant, or the small amount of leaves ingested, was not sufficient for the animal to associate strongly the aversive agent that caused the post-ingestive distress with consumption of the plant.

A striking fact observed in 3 goats in Group 1 and 1 goat in Group 2 that ingested I. carnea during the pasture challenge was that they did not eat the plant during the pen challenge on day 23. The same behavior was observed in the pen challenge on day 38, where all goats from both groups did not ingest the plant. Probably this occurred because the pasture where the goats were challenged was an unfamiliar environment, while the pens where the goats were averted was a familiar environment. The context of the aversion has been shown to be important, as heifers averted with $\mathrm{LiCl}$ and moved to an unfamiliar environment began to ingest the target plant, Delphinium barbeyi, but they ceased to ingest it when they returned to the familiar environment where the aversion was induced (Ralphs \& Olsen 1990).

The physiological state of the animals can affect the results of the aversion, for example, lactation is a state of increased energy requirements (Provenza 1995). Lactation probably enhanced the dams' appetites, thus providing a more stringent test of the aversion.

$\mathrm{LiCl}$ is effective in inducing a conditioned food aversion to certain plants, such as Cercocarpus montanus (Burritt \& Provenza 1989), Delphinium barbeyi (Ralphs 1997) and Amorimia rigida (Barbosa et al. 2008). The palatability of a plant can affect the persistence of the aversion. After LiCl-induced aversion to Leucaena leucocephala which is a palatable forage, goats reduced their consumption of this plant, but they were not averted completely. The aversion was eventually extinguished as the animals sampled L. leucocephala without negative gastrointestinal feedback (Górniak et al. 2008).

In this experiment, some goats that were averted with $B$. coridifolia presented clear signs of digestive disturbance after ingesting the plant, whereas no clinical signs were observed in the goats averted with LiCl. It is known that aversive agents that cause the greatest nausea in animals provoke the strongest aversion (Ralphs \& Cheney 1993). These authors showed that in cattle, higher dose levels of LiCl produce a more intense illness, which created stronger feedback associated with the taste of the target plant. The clinical signs of digestive upset after ingestion of $B$. coridifolia indicate a potentially stronger aversive effect in the goats in this group compared to the goats averted with $\mathrm{LiCl}$ that did not show any clinical signs. This observation held true during the course of the experiment.

The aversive effect of $B$. coridifolia is most likely due to the presence of macrocyclic trichothecenes, produced by soil fungi (Habermehl et al. 1985), which induce severe gastrointestinal lesions. It has been demonstrated that toxic plants can produce conditioned aversions to food, as shown for Xylorhiza glabriuscula, the toxic effect of which is due to their selenium content (Pfister et al. 2010).

The results of this study suggest that $B$. coridifolia or unknown bio-active secondary compounds within this plant can be used as aversive agents; and furthermore, the use of $B$. coridifolia as an aversive agent for livestock may have some advantages over the use of $\mathrm{LiCl}$. The labor requirement to dose $B$. coridifolia manually is intensive, although the technique is simple and requires little training. The cost of using LiCl for large herds of livestock would be substantial and perhaps beyond the means of many livestock owners in Brazil. In addition, dosing with $\mathrm{LiCl}$ requires the use of a stomach tube for oral gavage that must performed by trained personnel, which especially in the case of larger herds, may beyond the capability of many livestock producers dealing with Ipomoea spp. intoxication. 
Acknowledgements.- This research was supported by INCT/CNPq process no. 573534/2008-0, CNPq process no. 471365/2010-6 and CAPES (PROCAD-2009, case no. 646/2010). We thank Dr. Kristian Fog Nielsen's Department for Systems Biology of the Technical University of Denmark by trichothecenes determination.

\section{REFERENCES}

Alda J.L., Sallis E.S.V., Nogueira C.E.W., Soares M.P., Amaral L., Marcolongo-Pereira C., Frey Jr F. \& Schild A.L. 2009. Spontaneous Baccharis coridifolia (Compositae) poisoning in horses in southern Brazil. Pesq. Vet. Bras. 29(5):409-414.

Almeida M., Schild A.L., Assis-Brasil N., Quevedo P., Fiss L., Pfister J. \& Riet-Correa F. 2009. Conditioned aversion in sheep induced by Baccharis coridifolia. Appl. Anim. Behav. Sci. 117:197-200.

Almeida M.B., Schild A.L., Pfister J., Pimentel M., Forster K.M. \& Riet-Correa F. 2013. Methods of inducing conditioned food aversion to Baccharis coridifolia (mio-mio) in cattle. Ciência Rural. (In publication)

Antoniassi N.A.B., Ferreira E., dos Santos C., Arruda L., Campos J.L., Nakazato L. \& Colodel E.M. 2007. Spontaneous Ipomoea carnea subsp. fistulo$s a$ (Convolvulaceae) poisoning of cattle in the Brazilian Pantanal. Pesq. Vet. Bras. 27(10):415-418.

Armién A.G., Tokarnia C.H., Peixoto P.V. \& Frese K. 2007. Spontaneous and experimental glycoprotein storage disease of goats induced by Ipomoea carnea subsp fistulosa (Convolvulaceae). Vet. Pathol. 44:170-184.

Armién A.G., Tokarnia C., Peixoto P.V., Barbosa K. \& Frese K. 2011. Clinical and morphologic changes in ewes and fetuses poisoned by Ipomoea carnea subspecies fistulosa. J. Vet. Diagn. Invest. 23:221-232.

Barbosa R.R., Silva I.P. \& Soto-Blanco B. 2008. Development of conditioned taste aversion to Mascagnia rigida in goats. Pesq. Vet. Bras. 28(12):571-574.

Barros C.S.L. 1998. Livestock poisoning by Baccharis coridifolia, p.569572. In: Garland T. \& Barr A.C. (Eds), Toxic Plants and Other Natural Toxicants. CAB International, Wallingford, UK.

Bernstein I.L. 1999. Taste aversion learning: a contemporary perspective. Nutrition 15:229-234.

Burritt E.A. \& Provenza F.D. 1989. Food aversion learning: conditioning lambs to avoid palatable shrub (Cercocarpus montanus). J. Anim. Sci. 67:650-653.

Burritt E.A. \& Provenza F.D. 1990. Food aversion learning in sheep: persistence of conditioned taste aversions to palatable shrubs (Cercocarpus montanus and Amelanchier alnifolia). J. Anim. Sci. 68:1003-1007.

De Balogh K.I.M., Dimande A.P., Van der Lugt J.J., Molyneux R.J., Naudé T.W. \& Welman W.G. 1999. A lysosomal storage disease induced by Ipomoea carnea in goats in Mozambique. J. Vet. Diagn. Invest. 11:266-273.

Gardner D.R., Molyneux R.J. \& Ralphs M.H., 2001. Analysis of swainsonine: extraction methods, detection and measurement in populations of locoweeds (Oxytropis spp.). J. Agric. Food Chem. 49:4573-4580.

Gorniak S., Pfister J., Lanzonia E. \& Raspantini E. 2008. A note on averting goats to a toxic but palatable plant, Leucaena leucocephala. Appl. Anim. Behav. Sci. 111:396-401.

Grigson P.S., Shimura T. \& Norgren R. 1997. Brainstem lesions and gustatory function: III. The role of the parabrachial nucleus in retention of a conditioned taste aversion in rats. Behav. Neurosci. 111:180-187.

Habermehl G., Busam L., Heydel P., Mebs D., Tokarnia C., Döbereiner J. \& Spraul M. 1985. Macrocyclic trichothecenes: cause of livestock poisoning by the Brazilian plant Baccharis coridifolia. Toxicon 23:731-743.

Oliveira C.A., Barbosa J.D., Duarte M.D., Cerqueira V.D., Riet-Correa F. \& Riet-Correa G. 2009. Poisoning by Ipomoea carnea subsp. fistulosa in goats in the Marajó island, Pará. Pesq. Vet. Bras. 29(7):583-588.
Oliveira-Filho J.C., Carmo P.M.S., Iversen A., Nielsen K.F. \& Barros C.S.L. 2012. Experimental poisoning by Baccharis megapotamica var. weirii in buffalo. Pesq. Vet. Bras. 32(5):383-390.

Olsen J.D., Ralphs M.H. \& Lane M.A. 1989. Aversion to eating poisonous larkspur plants induced in cattle by intraruminal infusion with lithium chloride. J. Anim. Sci. 67:1980-1985.

Pacífico da Silva I. \& Soto-Blanco B. 2010. Conditioning taste aversion to Mascagnia rigida (Malpighiaceae) in sheep. Res. Vet. Sci. 88:239-241.

Pelchat M.L. \& Rozin P. 1982. The special role of nausea in the acquisition of food dislikes by humans. Appetite 3:341-351.

Pfister J.A., Gardner D.R., Cheney C.C., Panter K.E. \& Hall J.O. 2010. The capability of several toxic plants to condition taste aversions in sheep. Small Rumin. Res. 90:114-119.

Pimentel L.A., Maia L.A., Campos E.M., Dantas A.F.M., Medeiros R.M.T., Pfister J.A., Cook D. \& Riet-Correa F. 2012. Conditioned food aversion to control outbreaks of poisoning by Ipomoea carnea subsp. fistulosa and Turbina cordata in goats. Pesq. Vet. Bras. 32(8):707-714.

Provenza F.D. 1995. Postingestive feedback as an elementary determinant of food preference and intake in ruminants. J. Range. Manag. 48:2-17.

Provenza F.D., Burritt E.A., Clausen T.P., Bryant J.P., Reichardt P.B. \& Distel R.A. 1990. Conditioned flavor aversion: a mechanism for goats to avoid condensed tannins in blackbrush. Am. Nat. 136(6):810-828.

Ralphs M.H. 1997. Persistence of aversions to larkspur in naive and native cattle. J. Range. Manag. 50:367-370.

Ralphs M.H. \& Olsen J.D. 1990. Adverse influence of social facilitation and learning context in training cattle to avoid eating larkspur. J. Anim. Sci. 68:1944-1952.

Ralphs M.H. \& Cheney C.D. 1993. Influence of cattle age, lithium chloride dose level, and food type in the retention of food aversions. J. Anim. Sci. 71: 373-379.

Ralphs M.H. \& Provenza F.D. 1999. Conditioned food aversions: principles and practices, with special reference to social facilitation. Proc. Nutr. Soc. 58:813-820.

Reilly S., Grigson P.S. \& Norgren R. 1993. Parabrachial nucleus lesions and conditioned taste aversion: evidence supporting an associative deficit. Behav. Neurosci. 107:1005-1017.

Riet-Correa G. 2012. Unpublished results (Central de Diagnóstico Veterinário, Escola de Veterinária,Universidade Federal do Pará, Rua Maximino Porpino da Silva 1000, Pirapora, Castanhal, PA, 68743-080, Brasil).

Rissi D.R., Rech R.R., Fighera R.A., Cagnini D.Q., Kommers G.D. \& Barros C.S.L. 2005. Spontaneous Baccharis coridifolia poisoning in cattle. Pesq. Vet. Bras. 25(2):111-114.

Rozza D.B., Raymundo D.L., Corrêa A.M.R., Seitz A.L., Driemeier D. \& Colodel E.M. 2006. Spontaneous Baccharis coridifolia (Compositae) poisoning in sheep. Pesq. Vet. Bras. 26(1):21-25.

Silva D.M., Riet-Correa F., Medeiros R.M.T. \& Oliveira O.F. 2006. Toxic plants for livestock in the western and eastern Seridó, state of Rio Grande do Norte, in the Brazilian semiarid. Pesq. Vet. Bras. 26(4):223-236.

Tokarnia C.H., Döbereiner J. \& Canella C.F.C. 1960. Estudo experimental sobre a toxidez do "canudo" (Ipomoea fistulosa Mart.) em ruminantes. Arqs Inst. Biol. Animal, Rio de J., 3:57-71.

Tokarnia C.H., Brito M.F., Barbosa J.D., Peixoto P.V. \& Döbereiner J. 2012. Plantas Tóxicas do Brasil para Animais de Produção. 2ª ed. Editora Helianthus, Rio de Janeiro. 566p.

Yamamoto T., Nagai T., Shimura T. \& Yasoshima Y. 1998. The roles of chemical mediators in the taste system. Jpn. J. Pharmacol. 76:325-348. 